(c) 2017, Elsevier. Licensed under the Creative Commons Attribution-NonCommercialNoDerivatives 4.0 International

http: //creativecommons.org/licenses/by-nc-nd/4.0/

\title{
Investigating links between cultural orientation and culture outcomes: Immigrants from the former Soviet Union to Israel and Germany
}

\begin{abstract}
Marketers are justifiably interested in ethnic consumers; formulating effective ethnic marketing strategies requires insights into these consumers' attitudes and behaviors. However, prior research provides few insights into how different cultural environments might shape the consumption behavior of consumers with the same cultural heritage. To address this knowledge gap, the present study examines the cultural orientation and relevant consumer outcomes (i.e., desire for unique products and fashion consciousness) of immigrants from the former Soviet Union who move to Israel and Germany. The results reveal differences in the cultural orientations of immigrants to Israel versus Germany, as well as different relational patterns between cultural orientation and the proposed consumer outcomes. These findings provide both theoretical and managerial implications.
\end{abstract}

Keywords: cultural orientation, acculturation, consumption, unique products, fashion 


\section{Introduction}

Continuing migration into highly developed regions, especially but not exclusively into North America and the European Union, prompts acculturation processes at individual levels. Acculturation, or the acquisition of aspects of a mainstream (i.e., host) culture (Cleveland \& Laroche, 2007; Laroche, Kim, \& Tomiuk, 1998), shapes consumers' self-identities, attitudes, and behaviors (Berry, Phinney, Sam, \& Vedder, 2006a). Immigrant consumers, even from the same generation or family, do not necessarily acculturate the same way though (Berry, 1997). They choose, or perhaps are confined to, particular acculturation paths, which largely determine which products they buy and consume (Gbadamosi, 2012; Reilly \& Wallendorf, 1987; Segev, Ruvio, Shoham, \& Velan, 2014). For example, acculturation paths depend on the degree to which migrants withstand a host culture's assimilationist pressures (Padilla, 2006; Sánchez \& Fernández, 1993).

Prior research provides robust evidence that consumers' respective ethnic identities, coupled with the extent to which they adopt a mainstream cultural environment, influence their consumption behaviors (e.g., Jamal \& Shukor, 2014; Jun, Ball, \& Gentry, 1993; Peñaloza, 1994). For example, Deshpande, Hoyer, and Donthu (1986) show that Hispanic consumers in the United States who strongly identify with their culture of origin use Spanish language media more heavily and express more negative attitudes toward mainstream businesses than those who identify weakly with it. Segev et al. (2014) examine and confirm an acculturation-brand loyalty link, using data from Hispanic consumers in the United States and Russian immigrants in Israel.

Despite such advances in understanding the relationship between acculturation and consumer behavior, no research reveals how different cultural environments might distinctly shape the consumption behavior of consumers from the same cultural heritage. Most studies 
instead focus on a single group of consumers from one culture (Peñaloza, 1994) or groups of consumers from different cultures (Laroche, Kim, Tomiuk, \& Belisle, 2005) who move to another, single mainstream culture. However, continuing migration makes it pertinent to consider how new mainstream cultures that embed migrant consumers from the same heritage culture might shape their consumption behaviors. Specifically, how does cultural orientation (toward the mainstream and heritage cultures) shape the consumption behavior of consumers from the same heritage culture in different cultural environments? Cultural orientation, or a person's connection to and orientation toward a cultural group's members, beliefs, values, and practices (Phinney, 1990), could affect consumption-related outcomes and inform firms' efforts to develop successful ethnic marketing strategies (Pires, 1999).

The present research investigates the links between the cultural orientation of immigrants from the same cultural origin in different host cultures and several relevant consumption outcomes in the apparel category, which represents a tangible reflection of consumers' selfidentity and acculturation (Chattalas \& Harper, 2007; Jamal \& Shukor, 2014; Seock \& Sauls, 2008). The two focal outcomes pertain to mainstream culture and heritage culture, in terms of desires for unique products or being fashionable. Drawing on a framework by Dimitrova, Chasiotis, Bender, and van de Vijver (2014), this study tests the proposed model and hypotheses (see Figure 1) with two samples of Russian-speaking consumers from the former Soviet Union (FSU) that migrated to either Israel or Germany. The sample comparison reveals cultural orientations toward mainstream versus heritage cultures. These samples also support tests of the effects of a mainstream or heritage culture orientation on outcomes in different cultural environments. 
These issues are important both conceptually and practically. Conceptually, to gain a better understanding of the effects of macro differences in host culture environments on the micro consumption behavior of ethnic consumers from the same cultural origin, international marketing scholars need to study these orientations in distinct cultural environments. This research investigates the hypothesized links using a model that previously has not been examined empirically in marketing; the parsimonious model should spark new empirical research. Practically, effective ethnic marketing demands knowledge about what drives consumer buying behavior, particularly in relation to fashion products.

\section{Research background}

2.1 Cultural orientation and contextual influences

When "groups of individuals sharing different cultures come into continuous first-hand contact," acculturation occurs (Redfield, Linton, \& Herskovitz, 1936, p. 149). Acculturation refers to the degree to which people learn and adopt the norms and values of a culture that differs from the one in which they grew up (Cleveland \& Laroche, 2007). Acculturation is conceptually similar to, but differs from, cultural orientation: The former entails the actual adoption of mainstream culture norms, values, and behaviors, whereas the latter refers to how immigrant consumers think and feel about mainstream and heritage cultures. Acculturation hence involves behavior; cultural orientation is a precursor of behavior. Because the two concepts are conceptually related, , acculturation literature is highly relevant for understanding the consumption behavior of immigrants in new cultural environments.

Research on acculturation tends to be based on Berry's (1980) widely accepted framework of two major dimensions: cultural maintenance and cultural adoption. Cultural maintenance refers to the extent to which immigrants retain specific characteristics of their heritage culture. 
Cultural adoption is the extent to which characteristics of a mainstream culture become part of the behavior and attitudes of the acculturating people (Lerman, Maldonado, \& Luna, 2009). The distinction between mainstream and heritage culture also suggests four acculturation paths: (1) integration, or the simultaneous maintenance of heritage culture (i.e., culture of origin) and acquisition of new (i.e., mainstream) culture; (2) assimilation, or the devaluation of the heritage culture and strong identification with the mainstream culture; (3) separation, with the maintenance of heritage culture and rejection of mainstream culture; and (4) marginalization, or rejection of both cultures (Berry, 1997). These paths define a person's own cultural identity. Various researchers (e.g., Berry, 1997; Bourhis, Moïse, Perreault, \& Senécal, 1997; Schwartz, Unger, Zamboanga, \& Szapocznik, 2010) emphasize that these individual cultural paths are influenced by contextual factors, particularly the acculturation climate in the host country (e.g., immigration history, current immigration policy). Acculturation paths interact with the attitudes of receiving society members toward migrants and vary across national contexts. For example, Dimitrova et al. (2014) show that Turkish immigrants exhibit varying acculturation levels in different European countries, and Yagmur and van de Vijver (2012) indicate that Turkish immigrants in Australia integrate better into mainstream society than their counterparts in various European countries. In other words, people from the same heritage culture may differ in their adjustment to a new cultural environment, depending on that environment. A close connection then might arise between immigrants' cultural orientation and receiving countries' immigration climate. This study examines a specific group who immigrate into Israel and Germany. Therefore, a comparison of these countries is pertinent, to depict their relevant similarities and differences as they relate to immigration history and current immigration policy. 


\subsection{Research context: Immigration in Israel and Germany}

Both Israel and Germany are important destinations, in terms of the many immigrants they have received in the past 50 years. Between its establishment and the end of 2012, about 3.1 million immigrants arrived in Israel. In 2014, more than $25 \%$ of the living Israeli population was born outside the country (Central Bureau of Statistics, 2014). Germany is the second most popular migration destination in the world, receiving more than $10 \%$ of all permanent immigration in Europe (OECD, 2014). In 2013, 16.5 million immigrants lived in Germany, accounting for $20.5 \%$ of the total population (Destatis, 2013).

In both countries, Russian-speaking immigrants account for a substantial share of the total immigrant group. Since the breakup of the FSU and the liberalization of emigration regulations at the end of the 1980s, emigration from the FSU increased considerably. The most prominent receiving countries have been Israel, Germany, and the United States (Tishkov, Zayinchkovskaya, \& Vitkovskaya, 2005). Between 1990 and 2013 more than 1.2 million emigrants from the FSU came to Israel, and two-thirds arrived between 1990 and 1999 (Central Bureau of Statistics, 2014). In the same period, Germany absorbed approximately 1.75 million migrants from the FSU (Dietz, 2000). Today in Israel, 39.4\% of the immigrants are from the FSU, forming the largest single migrant group and accounting for more than $15 \%$ of the Israeli population (Central Bureau of Statistics, 2013). In Germany, immigrants from the FSU are the third largest immigrant group, accounting for 7.5\% of all immigrants (Destatis, 2014).

Despite these general similarities, Israel and Germany differ considerably in their history and current perspectives on immigration. In Israel, immigration is an integral to national development (Stephan, Ybarra, Martínez, Schwarzwald, \& Tur-Kaspa, 1998). To encourage immigration, Israel deploys various policies and initiatives that assist and support new 
immigrants, such as financial support for the first six months of residence, tax reductions, scholarship programs, special retirement programs, and health care benefits (Ministry of Immigrant Absorption, 2014). With this historically open policy, Israel's society is not homogenous by any measure (e.g., ethnicity, culture, language). Kimmerling (2004, p. 295) describes Israel as "an aggregate of cultures and counter-cultures with varying degrees of autonomy and separate institutional development within a common framework.” Klein (1987) deduces the legitimacy of the Israeli (Jewish) nation-state from its recognition of "nonassimilationist" policy toward cultural minorities, allowing immigrants their own language, schools, and so on. Similarly, Kretzmer (1990) views Israel's "anti-assimilationist" policies as proof of the nation's diligence in safeguarding the cultural traditions of minorities.

In contrast, Germany tries to avoid being perceived as an immigrant culture. The immigration policy has embraced the notion that "guest workers" (Gastarbeiter) enter the country, work and live in Germany for a couple of years, then return to their countries of origin (Zick, Wagner, van Dick, \& Petzel, 2001). Although Germany is a major immigrant-receiving country, the idea of Germany as an immigrant culture has never been accepted, as reflected in its current immigration policies. For example, German naturalization laws do not allow dual citizenship for adults. Applicants for naturalization must prove they have been habitual residents of Germany for eight years, demonstrate knowledge of Germany, and commit to national laws (Federal Foreign Office, 2014). Accordingly, Germany earns a low rank with regard to its multicultural policy, defined as "the degree to which governments and other administrative bodies promote cultural diversity as a national goal" (Berry, Westin, Virta, Vedder, Rooney, \& Sang, 2006b, p. 18). Schönwälder (2010, p. 153) emphasizes that "while the facts of past immigration and the resultant plurality of backgrounds and experiences in the German 
population are now accepted, this is not accompanied by a generally positive approach to cultural diversity and public representation of minorities as group." Rather, immigrants are expected to assimilate into German practices and culture; if they fail to do so, they are expected to leave (Zick et al., 2001). Friedrich Merz, a German conservative politician, highlights the need to "set rules for coexistence and assimilation that would eventually improve interethnic relations in Germany" (Manz, 2004, p. 485). Therefore, in contrast with Israel, Germany's immigration policy is oriented toward assimilation and seeks to avoid the idea of a multiethnic society. Germany tends to be a more "homogenous society culturally formed by mainstream values" (Tietzmann, Silbereisen, Mesch, \& Schmitt-Rodermund, 2011, p. 779). Israel represents a pluralistic society, whereas Germany is a more assimilationist culture. These different mainstream cultural environments likely shape consumer behavior.

\subsection{Acculturation and consumption}

Ethnic minority consumers display their cultural orientation and the extent to which they adopt the mainstream consumer cultural environment through their consumption of heritage and mainstream products. In growing literature on the consumption behaviors of ethnic minority consumers, focused on their cultural orientation (Deshpande et al., 1986; Lee \& Tse, 1994; Owenbey \& Horridge, 1997; Peñaloza, 1994), Reilly and Wallendorf (1987, p. 289) argue that immigrants consume ethnic and mainstream products as "complex expressions of overlapping social group membership." To express belonging to a certain (cultural or social) group, consumers adopt symbolic products, such as fashion, to communicate certain cultural meanings (Belk, 1988; McCracken, 1986) through intimate links to cultural categories (Stayman \& Desphande, 1989; Wattanasuwan, 2005). Consumption offers the potential to distinguish "the self” from “others" or communicate central beliefs and attitudes (Newholm \& Hopkinson, 2009). 
This study links cultural orientation to two symbolic consumer outcomes: the desire for unique products and fashion consciousness.

Unique products are goods that few others possess (e.g., rare, expensive, customized products) and help consumers express self-images (Zhan \& He, 2012). Consumers' need for uniqueness drives them to pursue dissimilarity through consumption, to develop a distinctive self and social image (Tian, Bearden, \& Hunter, 2001). However, the need for social approval may constrain the desire to be different. According to uniqueness theory (Snyder, 1992), consumers attempt to create and maintain their differentiation on essential self-related dimensions, associated with relevant peer groups. Prior research (e.g., Lynn \& Harris, 1997; Snyder \& Fromkin, 1980; Tian et al., 2001) argues that people in search of uniqueness tend to exhibit selfimages in ways that appear socially acceptable but avoid products that might provoke social sanctions. Studying the cultural orientations of British Muslims, Jamal and Shukor (2014) show that uniqueness can fulfill the needs for both differentiation and assimilation. Ethnic minority consumers seeking uniqueness hence might consume products that are valued as unique but also approved by significant others in their social contexts.

Fashion consciousness refers to the importance that consumers place on being in fashion, particularly with regard to their clothing (Shim \& Gehrt, 1996). Walsh, Mitchell, and HennigThurau (2001) find that fashion consciousness relates to a desire for up-to-date styles, frequent changes in the wardrobe, and pleasurable shopping experiences. Consumed in public and private settings, fashion has an important role for expressing both the inner self (Moody, Kinderman, \& Sinha, 2010) and a cultural identity or group affiliation (Barnard, 2002), so it provides an important mechanism for connecting with reference groups (Piacentini \& Mailer, 2004). 
As an externally visible characteristic, apparel also serves two functions: to integrate the person with the mainstream culture, reflecting a mainstream cultural orientation, or to signal a heritage culture affiliation, implying a heritage cultural orientation. Minority groups consume mainstream clothes to affiliate with the host community (Gbadamosi, 2012) or express cultural ethnic affiliations in their fashion choices (Chattaraman \& Lennon, 2008), as well as their choices of fashion-related ethnic products, such as movies and music (Xu, Shim, Lots, \& Almeida, 2004). Being fashionable and desiring unique products together reflect cultural selfimages and signal ethnic minority consumers' cultural self-locations (heritage versus host culture). The next section, based on the cultural differences between Israel and Germany, introduces hypotheses regarding the effects of cultural orientation on culture outcomes, in terms of desire for unique products and fashion consciousness.

\section{Hypotheses development}

Minority immigrant groups cannot always pursue the acculturation path they prefer (Berry, 1997). Depending on the views of the host society (assimilationist or pluralist), the degree to which immigrant groups feel free to maintain aspects of their heritage culture and/or adapt to the dominant culture of the host society varies. Several cross-cultural studies (e.g., Bond \& Smith, 1996; Croucher, 2009; Matthews, 2006; Ruggiero, Taylor, \& Lambert, 1996) that compare the

pressure exerted by receiving societies on immigrants to conform to cultural and societal patterns indicate that higher levels of host conformity pressure are likely in more assimilationist countries (e.g., Germany), but lower levels mark multicultural environments (e.g., Israel) that encourage immigrants to maintain their ethnic identities (Croucher, 2006; Ruggiero et al., 1996).

In response, migrants in assimilationist cultures may try to fit in and follow the societal patterns of the majority, such as by adapting their names to the host culture, speaking the host 
country language, or adopting mainstream-related clothing styles and products (Berry, 2005;

Katz \& Taylor, 1988). This kind of conformity is fundamental to group and cultural processes (Asch, 1952; Furnham, 1984). Moscovici (1980) argues though that when host cultures exert conformity pressure, migrants publicly accept the majority view (i.e., external conformity) to avoid possible negative sanctions (e.g., economic penalties; Li, 2004) while privately retaining their initial values and views (i.e., internal conformity). External conformity behavior likely takes place when the individual behavior is visible to members of the host culture, such as when immigrants exhibit unique mainstream products or fashions in a mainstream sense (Mourali, Laroche, \& Pons, 2005). The conformity pressure in assimilationist cultures likely pushes migrants to try to suit the environment and integrate visually into the mainstream culture. This conformance with general expectations occurs regardless of whether migrants have a low or high mainstream cultural orientation. As Croucher (2006) shows, second-generation Muslim migrants in France (assimilationist environment) adapt to the host culture by speaking mainly French, reading French newspapers and books, and wearing typical French clothes, so they can obtain social approval and economic success, not out of genuine conviction. In a similar vein, Ruggiero et al.'s (1996) study, conducted in the assimilationist United States (Padilla, 2006), indicates that higher levels of assimilation pressure and discrimination motivate Hispanic-Americans to hide their heritage identity and visually assimilate with the host culture. In such cultures, where migrants (with both low and high mainstream cultural orientations) do not want to stand out for the "wrong reasons," unique mainstream-related products and being fashionable in a mainstream sense help them fit in to the mainstream cultural environment.

In contrast, societies that support cultural pluralism, such as Israel, are less likely to impose cultural change on immigrants (Berry, 1997; Murphy, 1965). Accordingly, migrants with low 
mainstream cultural orientations are not enmeshed in systems of obligations to the host culture but are relatively free "to do their own thing" (Berry, 2004). As Gbadamosi (2012) shows, Black African women in London (pluralistic environment) freely express their affiliation with either their host or their heritage culture by buying and using mainstream or heritage clothing. Thus, in pluralist cultures, migrants who embrace the values, attitudes, and behaviors of the host country adapt their social patterns to express their identification with the mainstream culture, but migrants with a low mainstream cultural orientation likely choose heritage-related products to affiliate with their heritage culture.

Taken together, the differences in the immigration-related policies of Israel and Germany may affect migrants' acculturation behavior. In a more assimilationist culture like Germany migrants have relatively little freedom to choose how they want to acculturate. Whether they have low or high mainstream cultural orientations, migrants may try to fit in visually with the mainstream cultural environment, by using unique mainstream products and being fashionable in a mainstream sense. Accordingly, the effect of mainstream cultural orientation on mainstream cultural outcomes may be weak or nonexistent in an assimilationist culture like Germany. In contrast, in a more pluralist culture like Israel, lower levels of host conformity pressure lead to stronger effects of mainstream cultural orientations on mainstream-related outcomes. Migrants with a low mainstream cultural orientation likely avoid mainstream-related products and overtly express affiliations with their heritage culture. Migrants high on mainstream cultural orientation instead might visually emphasize their identification with the host culture by using unique mainstream products and being fashionable in a mainstream sense.

H1. Mainstream cultural orientation more strongly predicts the desire for unique mainstream culture products in Israel than in Germany. 
H2. Mainstream cultural orientation more positively predicts mainstream fashion consciousness in Israel than in Germany.

Unique heritage products and heritage fashion choices provide important mechanisms for connecting with members of the heritage culture. Migrants who embrace the heritage culture likely buy and exhibit heritage culture-related, unique products or express cultural ethnic affiliations in their fashion choices, because doing so is a way to celebrate their heritage culture (Chattaraman \& Lennon, 2008). However, more assimilationist cultures expect immigrants to abandon their own cultural distinctiveness for the sake of adopting the culture and values of the host society (Bourhis et al., 1997). Ruggiero et al. (1996) note that the perceived discrimination of immigrants in assimilationist environments leads to decreased heritage culture maintenance. In other words, migrants in more assimilationist cultures, like Germany, are less likely to express their heritage culture orientation by exhibiting unique heritage products or being fashionable in a heritage sense.

H3. Heritage cultural orientation more strongly predicts the desire for unique heritage culture products in Israel than in Germany.

H4. Heritage cultural orientation more positively predicts heritage fashion consciousness in Israel than in Germany.

\section{Method: Sample and questionnaire}

Respondents in both countries completed a printed questionnaire. All measures came from prior literature and were anchored at 1 ("strongly disagree") and 5 ("strongly agree"). To measure cultural orientations and consumer outcomes toward both the mainstream and the heritage culture, a common approach presents participants with identical items that refer to both cultures separately (Tsai, Ying, \& Lee, 2000). The current study similarly used a bilinear 
conceptualization of all measures. Four items to measure cultural orientation came from Demes and Geeraert (2014). The desire for unique products measure included three items adapted from Lynn and Harris (1997). Three items from Shim and Gehrt (1996) measured fashion consciousness (see Appendix for detailed scale information). In addition, respondents' gender $($ male $=0 ;$ female $=1)$ and age served as covariates in the model.

Among the Israeli respondents, the median age was 28 years $(\mathrm{SD}=12.74)$, ranging from 18 to 80 years, and $57.3 \%(n=168)$ of respondents were women (Table 1$)$. The median age of the German respondents was 35 years $(\mathrm{SD}=12.61)$, ranging from 17 to 70 years, and $34.4 \%(\mathrm{n}=$ 65) were women. Compared with the Israeli sample, the German sample contains more male and older participants.

-- Table 1 here -

\section{Results}

\subsection{Cross-cultural measurement invariance}

To assess invariance across the Israeli and German samples, the authors examine the data for similar patterns of factor loadings (configural invariance), equality of factor loadings (metric invariance), and equality of intercept terms (scalar invariance). In AMOS 19, using the measurement invariance test proposed by Milfont and Fisher (2010), a multigroup confirmatory factor analysis (CFA) defined two groups by country. The model fit the data well $\left(\chi^{2}(220)=\right.$ $468.21, p<.05$; root mean square error of approximation [RMSEA] $=.048$; confirmatory fit index $[\mathrm{CFI}]=.93$; normed fit index $[\mathrm{NFI}]=.88$; goodness-of-fit index $[\mathrm{GFI}]=.91$; see Table 2). The analysis supported configural invariance; the same basic factor structure held for both groups and the proposed model. To test for metric invariance, an added constraint forced the factor loadings to be equal across groups. Again the model showed adequate fit $\left(\chi^{2}(236)=\right.$ 494.38, $p<.05 ; \mathrm{RMSEA}=.048 ; \mathrm{CFI}=.92 ; \mathrm{NFI}=.87 ; \mathrm{GFI}=.90 ;$ Table 2). The increase in $\chi^{2}$ 
was insignificant, indicating the equality of the factor loadings and full measurement invariance. Finally, another added constraint forced the intercepts to remain the same across the two groups. The model showed satisfactory fit $\left(\chi^{2}(252)=839.19, p<.05 ; \mathrm{RMSEA}=.071 ; \mathrm{CFI}=.83, \mathrm{NFI}=\right.$ .78; Table 2). The increase in $\chi^{2}$ from the baseline model was significant, indicating no equality of the intercepts across groups. These results provide evidence of configural and metric invariance but not scalar invariance in the measurement model.

-- Table 2 here -

\subsection{Measurement assessment}

A CFA is applied to the key constructs to examine the psychometric properties of the multi-item scales. Using a pooled sample of the Israeli and German data, the results offer evidence of the adequacy of the proposed measurement model $\left(\chi^{2}(175)=365.97, p<.05\right.$; RMSEA $=.048 ; \mathrm{CFI}=.96 ; \mathrm{NFI}=.92 ; \mathrm{GFI}=.94)$. Then further assessments of the measurement model test its construct reliability, convergent validity, and discriminant validity (Fornell \& Larcker, 1981), again with a pooled sample of Israeli and German respondents' data. The descriptive statistics for the principal constructs and their correlations appear in Table 3 . The Cronbach's alphas for all model constructs reached the threshold of .70 (Nunnally, 1978), so the constructs are internally consistent. Four methods serve to assess convergent and discriminant validity. First, the square roots of the average variance extracted (AVE) of all constructs are much greater than all other cross-correlations. Second, the AVEs are .50 or greater, with the exception of desire for unique products from the mainstream culture, which is slightly lower $(\mathrm{AVE}=.49)$. Third, the composite reliability of all constructs is well above the .70 threshold (Nunnally \& Bernstein, 1994). Fourth, the correlations among all constructs are below the .70 threshold, so they are distinct from one another. 


\subsection{Hypotheses testing}

A multigroup structural equation model using the critical ratio difference provides the tests of H1-H4 (Byrne, 2010). The model fit the data reasonably well $\left(\chi^{2}(358)=826.75, p<.05\right.$; RMSEA $=.052 ; \mathrm{CFI}=.90 ; \mathrm{NFI}=.83 ; \mathrm{GFI}=.88$,). As predicted in $\mathrm{H} 1$, the multigroup analysis indicates that the effect of mainstream cultural orientation on desiring unique mainstream products is significantly stronger among FSU-Israeli immigrants $(b=.611)$ than among FSU immigrants to Germany $(b=.123 ; z=-5.189, p<.001)$ (Table 4). In both countries, orientation to the mainstream culture strongly predicts being fashionable. Consistent with $\mathrm{H} 2$, the effect of mainstream cultural orientation on mainstream fashion consciousness in the Israeli model $(b=$ $.812)$ is stronger than that in the German model $(b=.178 ; z=-5.503, p<.001)$. In support of $\mathrm{H} 3$, the effect of heritage cultural orientation on the desire for unique heritage products is stronger among FSU immigrants to Israel $(b=.536)$ than among immigrants in Germany $(b=.298 ; z=-$ 2.081, $p<.01)$. Finally, in contrast with H4, no effect emerges for the link between heritage cultural orientation and heritage fashion consciousness for the Israeli $(b=.249)$ or German $(b=$ $.303 ; z=-.115, p>.05)$ samples.

-- Table 4 here -

\section{Discussion}

This study focuses on whether minority groups of the same heritage culture, living in different host countries, vary in their cultural orientations and consumption outcomes. The differences in the immigration history and current policies of the receiving countries suggest that, based on the stronger assimilation patterns (i.e., orientation toward mainstream culture) in Germany, the effect of both mainstream and heritage cultural orientations on cultural outcomes should be stronger for FSU immigrants to Israel than for FSU immigrants to Germany. The results largely confirm these predicted relationships; the cultural orientations of the same 
immigrant group can differ across countries. The multiethnic context of Israel enables FSU immigrants to maintain their heritage culture to a greater extent, mainly based on strong intraethnic relations. In contrast, FSU immigrants in Germany face an expectation to adapt to the host culture, in line with Germany's assimilation-oriented immigration policy. This study contributes to a deeper understanding of the role of macro context factors, such as the immigration policy of the receiving country, in acculturation processes. The findings also affirm prior work (Dimitrova et al., 2014; Yagmur \& van de Vijver, 2012) that highlights the cultural orientation of immigrants as a function of both individual choices and contextual factors.

\subsection{Theoretical implications}

The macro environment has a critical influence on micro-ethnic consumption behavior (Cleveland \& Laroche, 2007; Ger \& Belk, 1996). This finding fills in an important missing piece in previous findings regarding the micro effects of consumers' ethnic identities on their willingness to adapt to a mainstream cultural environment (Jamal \& Shukor, 2014; Jun et al., 1993; Peñaloza, 1994). As this study shows, the acculturation orientations of migrants and their consumption patterns do not emerge in a social or political vacuum but rather depend strongly on the immigration history and policy of the host culture.

These results also reveal different relational patterns between cultural orientation and the desire for unique products or being fashionable. In line with the conceptual framework and hypotheses, mainstream cultural orientation is a strong predictor of both being fashionable and desiring unique mainstream products. A heritage cultural orientation predicts heritage culture outcomes in the Israeli and German subsamples but not the overall sample, which might reflect the Simpson (1951) paradox by which a trend in different groups of data disappears or reverses for the combined groups. The significant paths between heritage cultural orientation and relevant 
consumer outcome variables in both country samples are consistent with previous studies (e.g., Chung \& Fischer, 1999; Xu et al., 2004), which indicate that higher levels of heritage cultural orientation influence the consumption of products from that heritage culture. However, the level of conformity pressure exercised by the host society also strongly affects these consumption patterns. In summary, the present study addresses whether contextual factors influence the acculturation process, as well as the precise nature of the role that context plays for acculturation and fashion-related consumption patterns of migrants.

These findings reflect the broader context of acculturation processes. Incorporating these findings with previous literature suggests that acculturation can occur on different levels. At the micro level, acculturation relates to individual factors, such as personal traits, values, and behaviors (Béji-Bécheur, Özçağlar-Toulouse, \& Zouaghi, 2012; Jamal \& Shukor, 2014). On a pseudo-individual level, acculturation is associated with individual-level social influences (Jamal \& Shukor, 2014). The present study cites the macro-level, cultural environment and contributes to an integrative, multilevel view of acculturation that may spur further research into the interplay across these levels and consumption behavior.

In addition, the type of product under study is critical. The present study focuses on product categories that are self-expressive (Mehta \& Belk, 1991) and culturally embedded (Aaker, Benet-Martinez, \& Garolera, 2001), such that they might be more sensitive to macromicro cultural interactions and situational factors. Ethnic consumers might be less sensitive to or express ethnic preferences in more socially safe product categories-especially in cultural environments that expect assimilation, such as Germany. The macro and situational factors also might motivate consumers to trade off between product categories in ways that do not necessarily align with their personal preferences (Cleveland, Laroche, \& Hallab, 2013). Further 
research could help explicate the effect of such macro factors on immigrants' consumption behavior.

\subsection{Managerial implications}

These findings indicate that international managers must be cognizant of the complexity in most markets, resulting from diverse, multicultural societies. Many firms, especially in the apparel and fashion markets, respond to this increasing complexity by adapting their marketing mix strategies to target ethnic minority consumers (Holland \& Gentry, 1999; Mummert, 1995). Such marketing strategies and advertising campaigns are tailored to the cultural background of ethnic segments, with a supposition of homogenous ethnic submarkets. However, segmentation at the individual level (as is common), without considering the macro cultural context, might lead to inaccurate marketing executions. International marketers targeting transnational segments based on their heritage culture thus would be ill advised to assume homogeneity. Yagmur and van de Vijver (2012) report different acculturation paths for immigrant Turks in different countries; the current study similarly indicates that immigrant groups are heterogonous, with varying cultural orientations in different countries, and do not conform with traditional, ethnicity-based segmentation criteria. Managers should acknowledge that acculturation is a transformative process, so immigrants' consumption behavior varies in relation to the context.

In terms of targeting ethnic consumers (Pires, Stanton, \& Stanton, 2011), immigrants are “border consumers" (Peñaloza, 1994, p. 51), which makes it difficult to target them using just sociodemographic criteria. Within- and across-country segmentation and targeting of specific ethnic consumer groups should note the importance of context specificity for acculturation and consumption processes. Although both cultural orientations predict heritage and mainstream cultural outcomes for FSU immigrants, they also offer international marketers an indication of 
which culture to emphasize when communicating with a target group, according to the acculturation climate in the receiving society.

\subsection{Limitations and future research}

Researchers should adopt longitudinal research designs to gain greater insights into the influence of contextual factors on cultural orientation and subsequent behaviors, including clarifications of when and why cultural orientations might change in different countries, to highlight implications for consumer behavior. Furthermore, this analysis is restricted to a particular immigrant group but could be expanded to other groups and cultural settings. Migrants from countries such as Bangladesh, Greece, the Philippines, Syria, or Turkey might be studied in multiple host cultures. Prior literature indicates that four main state ideologies (pluralist, civic, assimilationist, and ethnist) shape the acculturation of immigrants in receiving societies (Bourhis et al., 1997). Studying minority groups prototypical of each of these four ideologies could increase insights into the relevance of contextual conditions for ethnic minorities' consumer behavior. The present study also measures migrants' cultural orientation at the individual level, without clustering participants by their acculturation path. Further research could examine the influence of different acculturation paths (i.e., integration, assimilation, separation, marginalization) in the cultural context-acculturation-consumption link.

Moreover further studies might expand knowledge about ethnic marketing to migrant groups by exploring the links between cultural orientation and relevant consumption outcomes with respect to different product categories, to facilitate international marketing activities. Immigrants often use fashion and unique products to express their identities or belonging to heritage or mainstream cultures (Jamal \& Shukor, 2014). Identifying other products could be useful for international marketers. 
Finally, the current study considers two symbolic consumer outcomes (the desire for unique products and fashion consciousness). Future research could consider additional consumption outcome variables, such as brand engagement and loyalty which might differ depending on the consumer's cultural orientation (Ownbey and Horridge, 1997).

\section{References}

Aaker, J.L., Benet-Martinez, V., \& Garolera, J. (2001). Consumption symbols as carriers of culture: A study of Japanese and Spanish brand personality constructs. Journal of Personality and Social Psychology, 81(3), 492-508.

Asch, S.E. (1952). Effects of group pressure on the modification and distortion of judgments. In G. E. Swanson, T. M. Newcomb, \& E. L. Hartley (Eds.), Readings in social psychology (pp. 2-11). New York: Holt.

Barnard, M. (2002). Fashion as communication. London: Routledge.

Béji-Bécheur, A., Özçağlar-Toulouse, N., \& Zouaghi, S. (2012). Ethnicity introspected: Researchers in search of their identity. Journal of Business Research, 65(4), 504-510.

Belk, R.W. (1988). Possessions and the extended self. Journal of Consumer Research, 15(2), 139168.

Berry, J.W. (1980). Acculturation as varieties of adaptation. In A.M Padilla (Ed.), Acculturation: Theory, models, and some new findings (pp. 9-26). Boulder, CO: Westview Press.

Berry, J.W. (1997). Immigration, acculturation, and adaptation. Applied Psychology: An International Review, 46(1), 5-68. 
Berry, J.W. (2004). Fundamental psychological processes in intercultural relations. In D. Landis, J. Bennett \& M. Bennett (Eds.), Handbook of Intercultural Training (pp. 166-184). London: Sage Publications.

Berry, J.W. (2005). Acculturation: Living successfully in two cultures. International Journal of Intercultural Relations, 29(6), 697-712

Berry, J.W., Phinney, J.S., Sam, D.L., \& Vedder, P. (2006a). Immigrant youth in cultural transition: Acculturation, identity and adaptation across national contexts. Mahwah, NJ: Lawrence Erlbaum Associates.

Berry, J.W., Westin, C., Virta, E., Vedder, P., Rooney, R., \& Sang, D. (2006b). Design of the study: Selecting societies of settlement and immigrant groups. In J.W Berry, J.S. Phinney, D.L. Sam \& P. Vedder (Eds.), Immigrant youth in cultural transition: Acculturation, identity, and adaptation across national contexts (pp. 15-45). Mahwah, NJ: Erlbaum.

Bond, R. \& Smith P.B. (1996). Culture and conformity: A meta-analysis of studies using Ash's (1952b, 1956) line judgment task. Psychological Bulletin, 119(1), 111-137.

Bourhis, R.Y., Moïse, L.C., Perreault, S., \& Senécal, S. (1997). Towards an interactive acculturation model: A social psychological approach. International Journal of Psychology, $32(6), 369-386$.

Byrne, B.M. (2010). Structural equation modeling with AMOS: Basic concepts, applications, and programming. Mahwah, NJ, London: Erlbaum.

Central Bureau of Statistics (2013). Israel in figures 2013. Retrieved from: http://www.cbs.gov.il/reader/publications/israel_fig_e.htm.

Central Bureau of Statistics (2014). Statistical abstract of Israel 2014. Retrieved from: http://www.cbs.gov.il/reader/shnatonenew_site.htm. 
Chattalas, M., \& Harper, H. (2007). Navigating a hybrid cultural identity: Hispanic teenagers' fashion consumption influences. Journal of Consumer Marketing, 24(6), 351-357.

Chattaraman, V., \& Lennon, S.J. (2008). Ethnic identity, consumption of cultural apparel, and self-perceptions of ethnic consumers. Journal of Fashion Marketing and Management, 12(4), 518-531.

Chung, E., \& Fischer, E. (1999). It's who you know: Intracultural differences in ethnic product consumption. Journal of Consumer Marketing, 16(5), 482-501.

Cleveland, M., \& Laroche, M. (2007). Acculturation to the global consumer culture: Scale development and research paradigm. Journal of Business Research, 60(3), 249-259.

Cleveland, M., Laroche, M., \& Hallab, R. (2013). Globalization, culture, religion, and values: Comparing consumption patterns of Lebanese Muslims and Christians. Journal of Business Research, 66(8), 958-967.

Croucher, S.M. (2006). The impact of external pressures on an ethnic community: The case of Montréal`s Quartier Chinois and Muslim-French immigrants. Journal of Intercultural Communication Research, 35(3), 235-251.

Croucher, S.M. (2009). How limiting linguistic freedoms influences the cultural adaptation process: An analysis of the French Muslim population. Communication Quarterly, 57(3), 302-318.

Demes, K.A., \& Geeraert, N. (2014). Measures matter: Scales for adaptation, cultural distance, and acculturation orientation revisited. Journal of Cross-Cultural Psychology, 45(1), 91-109.

Deshpande, R., Hoyer, W.D., \& Donthu, N. (1986). The intensity of ethnic affiliation: A study of the sociology of Hispanic consumption. Journal of Consumer Research, 13(2), 214-220. 
Destatis (2013). Migration and integration. Retrieved from: https://www.destatis.de/DE/ZahlenFakten/GesellschaftStaat/Bevoelkerung/MigrationIntegr ation/Migrationshintergrund/Migrationshintergrund.html.

Destatis (2014). Migration in figures. Retrieved from: https://www.destatis.de/DE/ZahlenFakten/GesellschaftStaat/Bevoelkerung/MigrationIntegr ation/Migrationshintergrund/Tabellen/MigrationshintergrundStaatsangehoerigkeit.html;jses sionid=2083789C69E101106F9ABAA3ECC8E60D.cae1.

Dietz, B. (2000). German and Jewish migration from the former Soviet Union to Germany: background, trends and implications. Journal of Ethnic and Migration Studies, 26(4), 635652.

Dimitrova, R., Chasiotis, A., Bender, M., \& van de Vijver, F.J. (2014). Turks in Bulgaria and the Netherlands: A comparative study of their acculturation orientations and outcomes. International Journal of Intercultural Relations, 40(May), 76-86.

Federal Foreign Office (2014). Immigration act. Retrieved from: http://www.auswaertigesamt.de/EN/EinreiseUndAufenthalt/Zuwanderungsrecht_node.html.

Fornell, C., \& Larcker, D. (1981). Evaluating structural equation models with unobservable variables and measurement error. Journal of Marketing Research, 18(1), 39-50.

Furnham, A. (1984). Studies of cross-cultural conformity: A brief and critical review. Psychologia, 27(1), 65-72.

Gbadamosi, A. (2012). Acculturation: An exploratory study of clothing consumption among Black African women in London (UK). Journal of Fashion Marketing and Management, $16,5-20$. 
Ger, G., \& Belk, R.W. (1996). Cross-cultural differences in materialism. Journal of Economic Psychology, 17(1), 55-77.

Holland, J., \& Gentry, J.W. (1999). Ethnic consumer reaction to targeted marketing: A theory of intercultural accommodation. Journal of Advertising, 28(1), 65-77.

Jamal, A., \& Shukor, S.A. (2014). Antecedents and outcomes of interpersonal influences and the role of acculturation: The case of young British-Muslims. Journal of Business Research, 67(3), 237-245.

Jun, S., Ball, A.D., \& Gentry, J.W. (1993). Modes of consumer acculturation. Advances in Consumer Research, 20, 76-82.

Katz, P. A., \& Taylor, D. A. (1988). Eliminating racism: Profiles in controversy. New York: Plenum.

Kimmerling, B. (2004). Immigrants, settlers, natives: The Israeli state and society between cultural pluralism and cultural wars. Tel Aviv: Am Oved.

Klein, C. (1987). Israel as a nation-state and the problem of the Arab minoricy-In search of a status. Tel Aviv: International Center for Peace in the Middle East, 1-25.

Kretzmer, D. (1990). The legal status of the Arabs in Israel. Boulder, CO: Westview Press.

Laroche, M., Kim, C., \& Tomiuk, M.A. (1998). Italian ethnic identity and its relative impact on the consumption of convenience and traditional foods. Journal of Consumer Marketing, $15(2), 125-151$.

Laroche, M., Kim, C., Tomiuk, M.A., \& Belisle, D. (2005). Similarities in Italian and Greek multidimensional ethnic identity: Some implications for food consumption. Canadian Journal of Administrative Sciences, 22(2), 143-167. 
Lee, W.-N., \& Tse, D.K. (1994). Changing media consumption in a new home: Acculturation patterns among Hong Kong immigrants to Canada. Journal of Advertising, 13(1), 57-70.

Lerman, D., Maldonado, R., \& Luna, D. (2009). A theory-based measure of acculturation: The shortened cultural life style inventory. Journal of Business Research, 62(4), 399-406.

Li, P.S. (2004). Social capital and economic outcomes for immigrants and ethnic minorities. Journal of International Migration and Integration, 5(2), 171-190.

Lynn, M., \& Harris, J. (1997). The desire for unique consumer products: A new individual differences scale. Psychology \& Marketing, 14(6), 601-616.

Manz, S. (2004). Constructing a normative national identity: The Leitkultur debate in Germany, 2000/2001. Journal of Multilingual \& Multicultural Development, 25(5-6), 481-496.

Matthews, K.C. (2006). Perceived discrimination: Psychological and sociopolitical barriers. Journal of International Migration and Integration, 7(3), 367-388.

McCracken, G. (1986). Culture and consumption: A theoretical account of the structure and movement of the cultural meaning of consumer goods. Journal of Consumer Research, 13 (1), 71-84.

Mehta, R., \& Belk, R.W. (1991). Artifacts, identity, and transition: Favorite possessions of Indians and Indian immigrants to the United States. Journal of Consumer Research, 17(4), 398-411.

Milfont, T.L., \& Fischer, R. (2010). Testing measurement invariance across groups: Applications in cross-cultural research. International Journal of Psychological Research, 3(1), 112-131.

Ministry of Immigrant Absorption (2014). Publications for new immigrants. Retrieved from: http://www.moia.gov.il/English/InformationAndAdvertising/Advertising/Pages/default.asp $\mathrm{X}$ 
Moody, W., Kinderman, P., \& Sinha, P. (2010). An exploratory study: Relationships between trying on clothing, mood, emotion, personality and clothing preference. Journal of Fashion Marketing and Management: An International Journal, 14(1), 161-179.

Moscovici, S. (1980). Towards a theory of conversion behavior. In L. Berkowitz (Eds.), Advances in experimental social psychology (pp. 209-239). New York: Academic Press.

Mourali, M., Laroche, M., \& Pons, F. (2005). Individualistic orientation and consumer susceptibility to interpersonal influence. Journal of Services Marketing, 19(3), 164-173.

Mummert, H. (1995). Reaching ethnic markets. Target Marketing 18(11), 14-17.

Murphy, H.B.M. (1965). Migration and the major mental disorders. In M. B. Kantor (Ed.), Mobility and mental health (pp. 221-249). Springfield: Thomas.

Newholm, T., \& Hopkinson, G. (2009). I just tend to wear what I like: Contemporary consumption and the paradoxical construction of individuality. Marketing Theory, 9(4), 439-462.

Nunnally, J.C. (1978). Psychometric theory. New York: McGraw-Hill.

Nunnally, J.C., \& Bernstein, I.H. (1994). Psychometric theory. New York: McGraw-Hill.

OECD (2014). Is migration really increasing? Retrieved from: http://www.oecd.org/berlin/Ismigration-really-increasing.pdf.

Owenbey, S.F., \& Horridge, P.E. (1997). Acculturation levels and shopping orientations of AsianAmerican consumers. Psychology and Marketing, 14(1), 1-18.

Padilla, A.M. (2006). Bicultural social development. Hispanic Journal of Behavioral Sciences, 28(4), 467-497.

Peñaloza, L.N. (1994). Border crossings: A critical ethnographic exploration of the consumer. Journal of Consumer Research, 21(1), 32-55. 
Phinney, J.S. (1990). Ethnic identity in adolescents and adults: Review of research. Psychological Bulletin, 108(3), 499-514.

Piacentini, M., \& Mailer, G. (2004). Symbolic consumption in teenagers' clothing choices. Journal of Consumer Behaviour, 3(3), 251-262.

Pires, G.D. (1999). Domestic cross-cultural marketing in Australia: A critique of the segmentation rationale. Journal of Marketing Theory and Practice, 7(4), 33-44.

Pires, G.D., Stanton, J., \& Stanton, P. (2011). Revisiting the substantiality criterion: From ethnic marketing to market segmentation. Journal of Business Research, 64(9), 988-996.

Redfield, R., Linton, R., \& Herskovitz, M. (1936). Memorandum on the study of acculturation. American Anthropologist, 38(1), 149-152.

Reilly, M.D., \& Wallendorf, M. (1987). A comparison of group differences in food consumption using household refuse. Journal of Consumer Research, 14 (2), 289-94.

Ruggiero, K.M., Taylor, D.M. \& Lambert, W.E. (1996). A model of heritage culture maintenance: The role of discrimination. International Journal of Intercultural Relations, 20(1), 47-67.

Sánchez, J. I., \& Fernández, D. M. (1993). Acculturative stress among Hispanics: A bidimensional model of ethnic identification. Journal of Applied Social Psychology, 23(8), 654-668.

Schönwälder, K. (2010). Integration policy and pluralism in a self-conscious country of immigration. In S. Vertovec \& S. Wessendorf. (Eds.), The multiculturalism backlash: European discourses, policies and practices (pp. 152-169). London, New York: Routledge.

Schwartz, S.J., Unger, J.B., Zamboanga, B.L., \& Szapocznik, J. (2010). Rethinking the concept of acculturation: Implications for theory and research. American Psychologist, 65(4), 237-251. Segev, S., Ruvio, A., Shoham, A., \& Velan, D. (2014). Acculturation and consumer loyalty among immigrants: A cross-national study. European Journal of Marketing, 48(9/10), 1579-1599. 
Seock, Y., \& Sauls, N. (2008). Hispanic consumers' shopping orientation and apparel retail store evaluation criteria: An analysis of age and gender differences. Journal of Fashion Marketing and Management, 12(4), 469-486.

Shim, S., \& Gehrt, K.C. (1996). Hispanic and Native American adolescents: An exploratory study of their approach to shopping. Journal of Retailing, 72(3), 307-324.

Simpson, E. (1951). The interpretation of interaction in contingency tables. Journal of the Royal Statistical Society, Series B 13(2), 238-241.

Snyder, C.R. (1992). Product scarcity by need for uniqueness interaction: A consumer Catch-22 carousel? Basic and Applied Social Psychology, 13(1), 9-24.

Snyder, C.R., \& Fromkin, H.L. (1980). Uniqueness: The human pursuit of difference. New York: Plenum Press.

Stayman, D. M., \& Deshpande, R. (1989). Situational ethnicity and consumer behavior. Journal of Consumer Research, 16(3), 361-371.

Stephan, W.G., Ybarra, O., Martínez, C.M., Schwarzwald, J., \& Tur-Kaspa, M. (1998). Prejudice toward immigrants to Spain and Israel. Journal of Cross-Cultural Psychology, 29(4), 559576.

Tian, K.T., Bearden, W.O., \& Hunter, G.L. (2001). Consumers' need for uniqueness: Scale development and validation. Journal of Consumer Research, 28(1), 50-66.

Tietzmann, P.F., Silbereisen, R.K., Mesch, G.S., \& Schmitt-Rodermund, E. (2011). Migrationspecific hassles among adolescent immigrants from the former Soviet Union in Germany and Israel. Journal of Cross-Cultural Psychology, 42(5), 777-794.

Tishkov, V., Zayinchkovskaya, Z., \& Vitkovskaya, G. (2005). Migration in the countries of the former Soviet Union. Global Commission on International Migration, September, 1-43. 
Tsai, J.L., Ying, Y.-W., \& Lee, P.A. (2000). The meaning of "being Chinese" and "being American" variation among Chinese American young adults. Journal of Cross-Cultural Psychology, 31(3), 302-332.

Walsh, G., Mitchell, V.-W., \& Hennig-Thurau, T. (2001). German consumer decision-making styles. Journal of Consumer Affairs, 35(1), 73-95.

Wattanasuwan, K. (2005). The self and symbolic consumption. Journal of American Academy of Business, 6(1), 179-184.

Xu, J., Shim, S., Lots, S., \& Almeida, D. (2004). Ethnic identity socialization factors, and culturespecific consumption behavior. Psychology \& Marketing, 21(2), 93-112.

Yagmur, K., \& Van de Vijver, F.J.R. (2012). Acculturation and language orientations of Turkish immigrants in Australia, France, Germany, and the Netherlands. Journal of Cross-Cultural Psychology, 43(7), 1110-1130.

Zhan, L., \& He, Y. (2012). Understanding luxury consumption in China: Consumer perceptions of best-known brands. Journal of Business Research, 65(10), 1452-1460.

Zick, A., Wagner, U., van Dick, R., \& Petzel, T. (2001). Acculturation and prejudice in Germany: Majority and minority perspectives. Journal of Social Issues, 57(3), 541-557. 


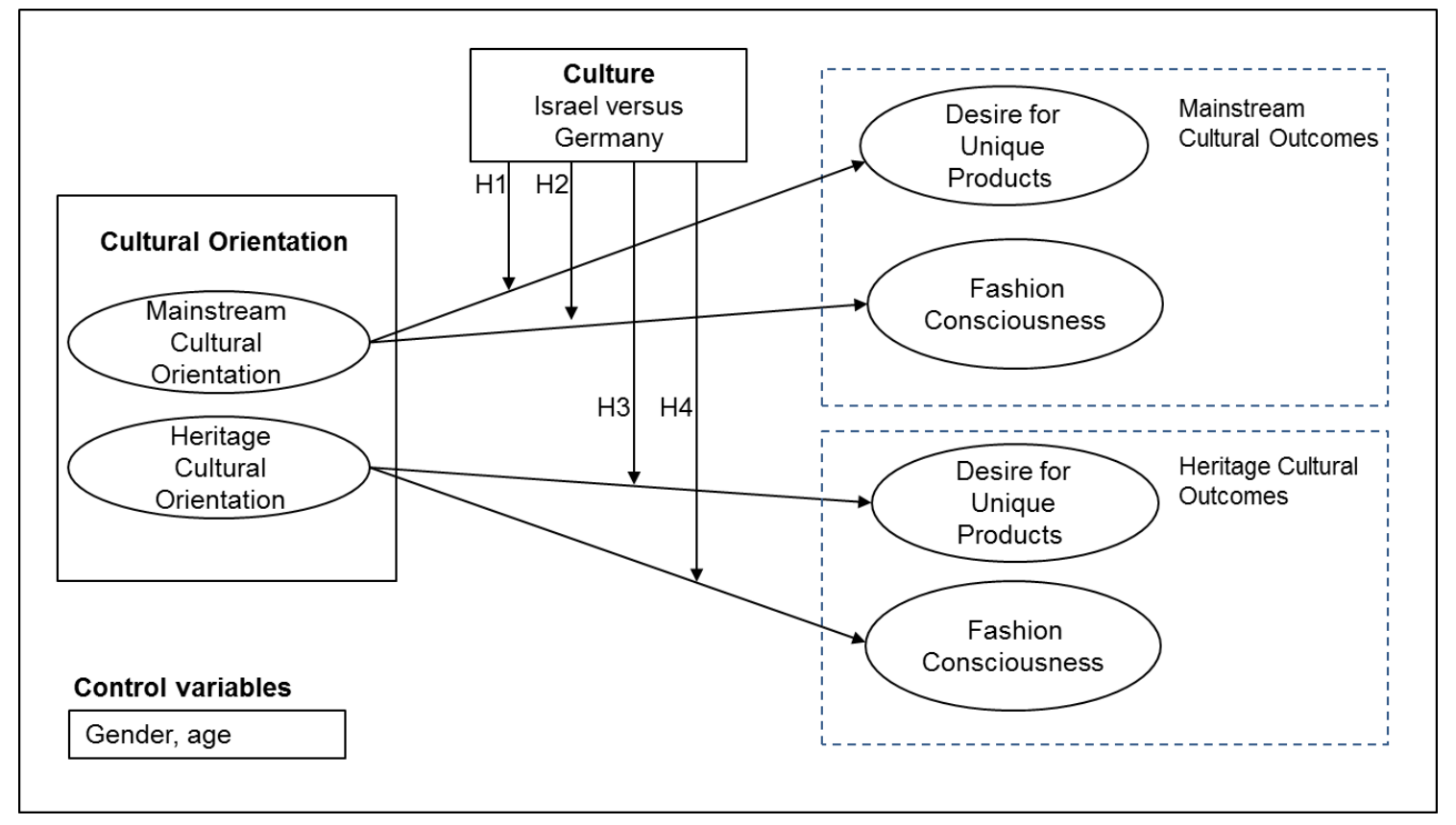

Fig. 1. Conceptual model 


\section{Table 1}

Sample characteristics, cultural orientations, and outcomes in Israel and Germany

\begin{tabular}{ccc}
\hline Constructs & Israel $(\mathrm{n}=293)$ & Germany $(\mathrm{n}=189)$ \\
Age Range & $18-80$ & $17-70$ \\
Median (SD) & $28(12.74)$ & $35(12.61)$ \\
Gender, $\mathrm{n}(\%)$ & & \\
Men & $125(42.7 \%)$ & $124(65.6 \%)$ \\
Women & $168(57.3 \%)$ & $65(34.4 \%)$ \\
Cultural orientation & & $3.92(.79)$ \\
Mainstream & $2.54(1.02)$ & $3.87(.99)$ \\
Heritage & $2.80(1.05)$ & \\
Desire for unique products & & $2.69(.99)$ \\
Mainstream & $2.68(1.20)$ & $2.40(1.01)$ \\
Heritage & $2.95(1.25)$ & \\
Fashion consciousness & & $2.95(1.25)$ \\
Mainstream & $2.56(1.29)$ & $1.91(.98)$ \\
Heritage & $2.77(1.14)$ & \\
\hline
\end{tabular}

\section{Table 2}

Measurement model invariance test

\begin{tabular}{lccccccc}
\hline Model & \multicolumn{1}{c}{$\chi_{(\mathrm{df})}^{2}$} & $\triangle \chi_{(\mathrm{df})}^{2}$ & RMSEA & CFI & NFI & GFI & $\begin{array}{c}\text { Equality } \\
\text { Supported }\end{array}$ \\
\hline $\begin{array}{l}\text { Configural } \\
\text { invariance }\end{array}$ & $468.21(220)$ & - & .048 & .93 & .88 & .91 & Yes \\
$\begin{array}{l}\text { Metric invariance } \\
494.38(236)\end{array}$ & $26.17(16)$ & .048 & .92 & .87 & .90 & Yes \\
Scalar invariance & $839.19(252)$ & $344.81(16)$ & .071 & .83 & .78 & - & No \\
\hline
\end{tabular}

Notes: RMSEA = root mean square error of approximation; CFI = confirmatory fit index; NFI = normed fit index. 


\section{Table 3}

Descriptive statistics and measurement assessment (pooled sample)

\begin{tabular}{|c|c|c|c|c|c|c|c|c|c|}
\hline Constructs & $\mathrm{M}(\mathrm{SD})$ & $\begin{array}{c}\text { Cronbach's } \\
\alpha\end{array}$ & CR & 1 & 2 & 3 & 4 & 5 & 6 \\
\hline 1. Mainstream cultural orientation & $\begin{array}{l}3.08 \\
(1.15)\end{array}$ & .82 & .82 & .73 & & & & & \\
\hline 2. Heritage cultural orientation & $\begin{array}{c}3.22 \\
(1.15)\end{array}$ & .81 & .79 & .68 & .71 & & & & \\
\hline $\begin{array}{l}\text { 3. Desire for unique mainstream } \\
\text { culture products }\end{array}$ & $\begin{array}{l}2.68 \\
(1.12)\end{array}$ & .75 & .75 & .35 & .23 & .70 & & & \\
\hline $\begin{array}{l}\text { 4. Desire for unique heritage } \\
\text { culture products }\end{array}$ & $\begin{array}{l}2.73 \\
(1.18)\end{array}$ & .78 & .77 & .08 & .24 & .48 & .72 & & \\
\hline $\begin{array}{l}\text { 5. Fashion consciousness } \\
\text { mainstream culture }\end{array}$ & $\begin{array}{c}2.71 \\
(1.29)\end{array}$ & .86 & .78 & .52 & .28 & .54 & .28 & .82 & \\
\hline $\begin{array}{l}\text { 6. Fashion consciousness heritage } \\
\text { culture }\end{array}$ & $\begin{array}{c}2.44 \\
(1.16)\end{array}$ & .76 & .86 & -.12 & -.03 & .29 & .45 & .20 & .73 \\
\hline
\end{tabular}

Notes: The diagonal elements (in bold) represent the square root of the average variance extracted. CR = composite reliability.

\section{Table 4}

Results of multigroup analyses for Israel and Germany

\begin{tabular}{lllll}
\hline Path & Overall & Israel & Germany & z-Value \\
\hline MCO $\rightarrow$ DUMP & $.519^{* * *}$ & $.611^{* * *}$ & $.123^{\mathrm{ns}}$ & $-5.189 * * *$ \\
$\mathrm{MCO} \rightarrow$ MFC & $.600^{* * *}$ & $.812^{* * *}$ & $.178^{*}$ & $-5.503^{* * *}$ \\
$\mathrm{HCO} \rightarrow$ DUHP & $.351^{* * *}$ & $.536^{* * *}$ & $.298^{* * *}$ & $-2.081^{* *}$ \\
$\mathrm{HCO} \rightarrow \mathrm{HFC}$ & $.013^{\mathrm{ns}}$ & $.249 * * *$ & $.303^{* *}$ & $-.115^{\mathrm{ns}}$ \\
\hline
\end{tabular}

Notes: Values associated with each path are standardized regression coefficients. $\mathrm{MCO}=$ mainstream cultural orientation; DUMP = desire for unique mainstream products; $\mathrm{MFC}=$ mainstream fashion consciousness; $\mathrm{HCO}=$ heritage cultural orientation; HFC $=$ heritage fashion consciousness; DUHP $=$ desire for unique mainstream products.

$* * * p<.001 . * * p<.01 . * p<.05 . \mathrm{ns}=$ not significant. 


\section{Appendix}

Items and item loadings

\begin{tabular}{lcc}
\hline & $\begin{array}{c}\text { Factor } \\
\text { Loadings, } \\
\text { Israel }\end{array}$ & $\begin{array}{c}\text { Factor } \\
\text { Loadings, } \\
\text { Germany }\end{array}$ \\
\hline Mainstream cultural orientation (adapted from Demes \& Geeraert, 2014) & .53 & .38 \\
\hline I associate with Israelis. & .70 & .54 \\
I enjoy listening to Hebrew language music. & .72 & .87 \\
I enjoy Hebrew language TV. & .71 \\
I like to identify myself as an Israeli. & .95 \\
\hline
\end{tabular}

Heritage cultural orientation (adapted from Demes \& Geeraert, 2014)

\begin{tabular}{lll}
\hline I associate with Russians. & .56 & .47
\end{tabular}

$\begin{array}{lll}\text { I enjoy listening to Russian language music. } & .71 & .84\end{array}$

$\begin{array}{lll}\text { I enjoy Russian language TV. } & .66\end{array}$

I like to identify myself as an Russian. $\quad .65 \quad .81$

Desire for unique mainstream products (adapted from Lynn \& Harris, 1997)

\begin{tabular}{ll}
\hline I am very attracted to rare Israeli products. & .73
\end{tabular}

.63

I am more likely to buy an Israeli product if it is scarce.

I would prefer to have Israeli things custom-made than to have them ready-made.

.70

Desire for unique heritage products (adapted from Lynn \& Harris, 1997)

I am very attracted to rare Russian products.

.72

.60

I am more likely to buy a Russian product if it is scarce.

.77

.93

I would prefer to have Russian things custom-made than to have them ready-made.

.75

.46

Fashion consciousness mainstream culture (adapted from Shim \& Gehrt, 1996)

I usually have one or more outfits of the very newest Israeli style.

.77

I keep my wardrobe up-to-date with the changing Israeli fashions.

.81

.93

Fashionable, attractive Israeli styling is very important to me.

Fashion consciousness heritage culture (adapted from Shim \& Gehrt, 1996)

I usually have one or more outfits of the very newest Russian style.

.59

I keep my wardrobe up-to-date with the changing Russian fashions.

Fashionable, attractive Russian styling is very important to me.

Notes: $\mathrm{N}=482$. All factor loadings are significant at $p<.001$. 